\title{
Higher Order Thinking Skills at Moral Learning
}

\author{
Asep Nursobah \\ Fakultas Tarbiyah dan Keguruan UIN Sunan Gunung Djati \\ Bandung, West Java, Indonesia \\ kangasnur@uinsgd.ac.id \\ Uus Ruswandi \\ Fakultas Tarbiyah dan Keguruan UIN Sunan Gunung Djati \\ Bandung, West Java, Indonesia \\ uusruswandi@uinsgd.ac.id
}

\author{
Andewi Suhartini \\ Fakultas Tarbiyah dan Keguruan UIN Sunan Gunung Djati \\ Bandung, West Java, Indonesia \\ andewi.suhartini@uinsgd.ac.id \\ Tuti Hayati \\ Fakultas Tarbiyah dan Keguruan UIN Sunan Gunung Djati \\ Bandung, West Java, Indonesia \\ thayati@uinsgd.ac.id
}

\begin{abstract}
Higher order thinking skills need to be owned by someone who lives in the 21 st century, to deal with the constantly changing environment and complex challenges. Aspects of thinking skills are also needed to determine moral actions in the sphere of character. Such thinking skills include critical and reflective thinking about the value attached to someone behavior. This study aims to examine the effect of problem-based learning model and learner independence on the ability of higher order thinking skills in learning Morals. This study uses a quantitative approach with the students of SMPN Purwakarta. The experimental design was used in this study to pilot the Problem Based Learning model. Data collection was done through tests and questionnaires. Data were analyzed with $3 \times 2$ factorial design. This research concludes problem-based learning and independence have positive and significant influence on higher order thinking skills of students of SMPN Purwakarta. Problembased learning and learner independence is an important aspect in the effort to improve the skills of higher order thinking in learning Morals.
\end{abstract}

Keywords - higher order thingking skills, leaner independence, problem based learning, moral learning componen

\section{INTRODUCTION}

Morality is a major competence in the PAI learning outcomes in schools. The manifestation of morals derived from the learning process is not just a mere habituation, but also learn to give consideration to the behavior based on the values that exist in the behavior. The ability to consider an action based on a value is in line with the thinking skills that learners have to possess by human resources living in the 21 st century. In this century, people are faced with a constantly changing environment and complex challenges, requiring moral qualities to face it, complete competence to overcome it and the core skills to live everyday life. Moral integrity, complex competence and core skills become the strength and stabilizer for someone who lives in this century. To instill moral values in the 21 st century human resources, it takes a high level thinking skill effort, in addition to the core skills in the learning process. Thinking is an important aspect in learning PAI aspects of Morals, both in the process and as a result of learning. The Islamic values he teaches, both faith, Islam and ihsan, are aspects of affection that require the introduction of high insight and thought to easily live and become personal characters.

The 2013 curriculum emphasizes that the competencies in the cognitive domain of junior high school students should be at the level of application and analysis. In the affective domain must be at a level of appreciation and appreciation. Similarly, in the skill domain of junior high school students should be able to serve and reason. Level of analysis, appreciate and appreciate, treat and reason, is a high-level thinking. This research will reveal the influence of problem-based learning model (PBL) to improve the ability of high-level thinking of learners on learning PAI aspect Akhlak.

\section{LITERATURE REVIEW}

The development of high-level thinking skills can be done through problem-solving by groups [1], analytical reasoning [2], and influenced by learning styles [3], teacher's ability in learning [4]. There are 30 learning strategies that can improve high-order thinking skills [5]. High-level thinking skills are the key determinants for the growth of ideas in students [6]

This study focuses on the learning process and the assessment of high-level thinking in learning PAI aspect Akhlak in SMPN Purwakarta as an important aspect to cultivate morals students.

\section{METHOD}

This research uses quantitative approach. Experimental method with $3 \times 2$ factorial analysis is used to test the effectiveness of problem-based learning model on high-order thinking ability of students of SMPN Purwakarta.

As a source of research data is used student population SMPN Purwakarta. The sample usage was done randomly in the SMPN analysis unit in Purwakarta by 3 SMPN as the experimental group and 3 SMPN as the control group.

Quantitative data is related to high-level learning outcomes in PAI learning, obtained through tests. Quantitative data is the result of quantification of theoretical constructs of high-order thinking skills on PAI learning arranged into test instruments. 
Quantitative data processing is done by technique of factorial statistic analysis which previously described and tested requirement (normality and homogeneity). Data analysis was done by using SPSS computer application.

\section{RESULT AND DISCUSSION}

\section{A. Description of All Data}

The results of the calculation of all pretest and posttest data through SPSS version 20 analysis shown in Table Descriptive obtained mean, standard deviation, standard error, minimum and maximum value and the difference between Problem Based Learning and Conventional Learning seen from Higher Learning Independence Level, Medium and Low at SMPN Purwakarta. Description of fabric data on learning results of PAI aspects of morality by using Problem Based Learning and Conventional Learning can be seen in the following table:

TABLE I. DESCRIPTION OF All DATA

\begin{tabular}{|l|l|l|l|l|c|c|}
\hline \multirow{3}{*}{$\begin{array}{c}\text { Indepen } \\
\text { dency }\end{array}$} & \multicolumn{6}{|c|}{ Learning Model } \\
\cline { 2 - 7 } & Problem Based Learning & \multicolumn{3}{c|}{ Conventional } \\
\cline { 2 - 7 } & Pres & Pos-tes & Gain & Pre-tes & $\begin{array}{c}\text { Pos- } \\
\text { tes }\end{array}$ & Gain \\
\hline High & 46,55 & 79,82 & 33,27 & 38,56 & 62,31 & 23,75 \\
\hline Middle & 32,61 & 71,35 & 38,74 & 31,63 & 49,75 & 18,12 \\
\hline Low & 22,41 & 58,41 & 36,00 & 20,00 & 35,00 & 15,00 \\
\hline
\end{tabular}

The table above clearly indicates that there is an increase in the average value of pretest and posttest from both groups (Problem Based Learning and Conventional) both from the level of learning independence of high, medium and low.

\section{B. Two-Dual Similarity Test}

Examining the two-averaged similarities aims to determine whether the two treatment groups have the same ability or not. This similarity test using the test-F test was conducted to test the basic assumption of $t$ test that both groups (Problem Based Learning and Conventional) have the same ability. Here is a summary of the results of the calculation:

TABLE II. SUMMARY OF AVERAGE EQUALITY TEST

\begin{tabular}{|c|c|c|c|c|c|c|c|}
\hline \multirow{4}{*}{$\begin{array}{c}\text { Indepen } \\
\text { dency }\end{array}$} & \multirow{2}{*}{\multicolumn{7}{|c|}{$\begin{array}{c}\text { Pre test } \\
\text { LEARNING MODEL }\end{array}$}} \\
\hline & & & & & & & \\
\hline & \multicolumn{2}{|c|}{ PBL } & \multicolumn{2}{|c|}{$\begin{array}{l}\text { CONVEN- } \\
\text { TIONAL }\end{array}$} & \multirow{2}{*}{$\mathbf{F}$} & \multirow{2}{*}{ df } & \multirow{2}{*}{ Sig } \\
\hline & $\bar{x}$ & $S d$ & $\bar{x}$ & $S d$ & & & \\
\hline High & 46,55 & 2,26 & 38,56 & 2,42 & \multirow{3}{*}{2,61} & \multirow{3}{*}{113} & \multirow{3}{*}{0.109} \\
\hline Middle & 32,61 & 6,74 & 31,63 & 2,94 & & & \\
\hline Low & 22,41 & 1,26 & 20,00 & 5,24 & & & \\
\hline
\end{tabular}

The result of SPSS version 20 analysis shows that the value of $F$ arithmetic $=2,611$ or $\operatorname{Sig}(0,109)>\alpha(0,05)$, then interpreted both group (Problem Based Learning and Conventional Learning) have the same ability.

\section{Test Prerequisites}

\section{1) Normality Test}

Normality test aims to determine whether the spread of normal data or not. If the data dissemination is not normal then the next hypothesis test will be done by using non parametric statistical method. This normality test uses KolmogorovSmirnov normality test at $\mathrm{p}$-value $\geq 0.05$ as follows:

TABLE III. ONE-SAMPLE KOLMOGOROV-SMIRNOV TEST

\begin{tabular}{|c|c|c|c|}
\hline & KemandPBL & Pretes & Posttest \\
\hline $\mathrm{N}$ & 67 & 67 & 67 \\
\hline Normal Mean & 146.1045 & 33.8358 & 69.7313 \\
\hline Parameters ${ }^{\mathrm{a}, \mathrm{b}}$ Std. Deviation & 18.30891 & 10.73171 & 10.90257 \\
\hline Absolute & .092 & 208 & .135 \\
\hline Positive & .052 & 208 & .100 \\
\hline Differences Negative & -.092 & -.151 & -.135 \\
\hline Kolmogorov-Smirnov Z & .751 & 1.706 & 1.108 \\
\hline Asymp. Sig. (2-tailed) & .626 & .006 & .171 \\
\hline
\end{tabular}

Table 3 One-Sample Kolmogorov-Smirnov The above test shows the results of normality test analysis with SPSS version 20 against the three variables (Learning Independence, Pretest and Posttest) on Problem Based Learning. Based on the result of analysis of Table 16 above, it can be concluded that:

1. Independence Learning on Problem Based Learning with Asymp. Sig (2-tailed $=0.626)>\alpha(0.05)$ so that it is interpreted to be normally distributed.

2. Pre Test on Problem Based Learning with Asymp. Sig (2tailed $=0.006)>\alpha(0,05)$ so that it is interpreted to be normally distributed.

3. Post Test on Problem Based Learning with Asymp. Sig (2tailed $=0.171)>\alpha(0.05)$ so that it is interpreted to be normally distributed.

Next Table 17 One-Sample Kolmogorov-Smirnov The test below is the result of normality test analysis on all three variables (Learning Independence, Pretest and Posttest) on Conventional Learning:

TABLE IV. ONE-SAMPLE KOLMOGOROV-SMIRNOV TEST

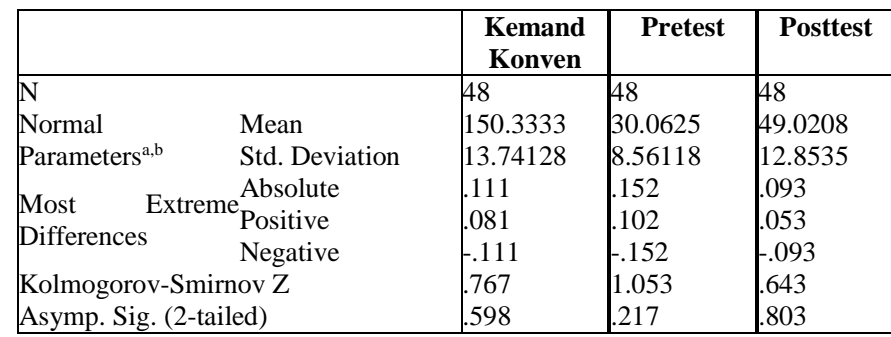

c. Test distribution is Normal.

d. Calculated from data.

Based on the results of the analysis of Table 4 above, it can be concluded that:

1. Independence Learning on Conventional Learning with Asymp. Sig (2-tailed $=0.598)>\alpha(0.05)$ so that it is interpreted to be normally distributed. 
2. Pre Test on Conventional Learning with Asymp. Sig (2tailed $=0.217)>\alpha(0.05)$ so that it is interpreted to be normally distributed.

3. Post Test on Conventional Learning with Asymp. Sig (2tailed $=0.803)>\alpha(0.05)$ so that it is interpreted to be normally distributed.

\section{2) Homogeneity Test}

Homogeneity test aims to determine whether the research data has a homogeneous variance or not. If the data variance is not homogeneous then the next Hypothesis test will be done by using non parametric statistical method. This homogeneity test was conducted on three groups of Learning Independence (high, medium, and low) Problem Based Learning and Conventional Learning. The SPSS 20 version calculation results are shown by the Test of Homogenety of Variances Table. The following is a summary of the results of the homogeneity test of Problem Based Learning (Table 5) and the homogeneity test of Conventional Learning (Table 6):

TABLE V. TeST OF Homogeneity of VARIANCES Problem BASED LEARNING

SkorPBL

\begin{tabular}{|c|c|c|c|}
\hline Levene Statistic & df1 & df2 & Sig. \\
\hline 24.156 & 2 & 64 & .285 \\
\hline
\end{tabular}

Table 5 above shows that the test results found that $\mathrm{F}$ calculated $=63.180$ with $\operatorname{sig}=0.285$. Because of the sig $>\alpha$ $(0,05)$ it can be concluded that the three groups of Learning Independence from Problem Based Learning have the same variant value or in other words the variance between groups is homogeneous.

TABLE VI. TEST OF HOMOGENEITY OF VARIANCES CONVENTIONAL LEARNING

Conventional Score

\begin{tabular}{|c|c|c|c|}
\hline Levene Statistic & df1 & \multicolumn{1}{c|}{ df2 } & Sig. \\
\hline .262 & 2 & 45 & .771 \\
\hline
\end{tabular}

Table 6 above shows that the test results found that $F$ arithmetic $=0.262$ with sig $=0.771$. Since sig $>\alpha(0,05)$, it can be concluded that the three groups of Learning Independence from Conventional Learning have the same variant value or in other words the variance between groups is homogeneous.

\section{Hypothesis Testing and Research Findings}

Hypothesis test was done by F-Anova factorial $3 \times 2$ with pvalue $\leq 0.05$.

First Hypothesis: There is a Difference in the Level of Thinking between Learners Using a Problem-Based Learning Model with the Conventional Model as a whole.

The result of SPSS version 20 analysis which is shown in statistics group table and independent samples table about the difference of thinking level between students of SMPN
Purwakarta using Problem Based Learning with Conventional Learning can be summarized in Table 7 below:

TABLE VII. SUMMARY OF INDEPENDENT SAMPLES TEST TABLE

\begin{tabular}{|c|c|c|c|c|c|c|c|c|}
\hline \multicolumn{4}{|c|}{ Learning Model } & \multirow{3}{*}{$\begin{array}{c}\text { differe } \\
\text { nt } \\
\text { increas } \\
\mathrm{e}\end{array}$} & \multirow{3}{*}{$\mathbf{F}$} & \multirow{3}{*}{$\mathbf{T}$} & \multirow{3}{*}{ df } & \multirow{3}{*}{ Sig } \\
\hline \multicolumn{2}{|c|}{$P B L$} & \multicolumn{2}{|c|}{ Konvensional } & & & & & \\
\hline $\bar{x}$ & $S d$ & $\overline{\bar{x}}$ & $S d$ & & & & & \\
\hline $\begin{array}{l}66,5 \\
8 \\
\end{array}$ & 9,52 & $\begin{array}{l}48,7 \\
5 \\
\end{array}$ & $\begin{array}{l}12,4 \\
6 \\
\end{array}$ & 18,13 & $\begin{array}{l}.60 \\
0\end{array}$ & 8,70 & 113 & $\begin{array}{l}0.02 \\
0\end{array}$ \\
\hline
\end{tabular}

Summary The Independent Samples Test table shows the difference test for the two groups. Based on the above calculation, it can be concluded that overall there are differences in high thinking ability of learners using ProblemBased Learning model (Problem Based Learning) with Conventional Learning. This conclusion is reinforced by the calculation result shown in table 20 above which shows the value $\mathrm{F}=5,600$ or $\operatorname{Sig}(0,020)<1 / 2 \alpha(0,025)$.

In addition, the value of $\mathrm{t}$ arithmetic $=8.700$ and the value of Sig (2-tailed $=0,000)<1 / 2 \alpha(0.05)$ it can be interpreted that problem-based learning affects the high thinking ability of students Purwakarta SMPN.

Second Hypothesis: There is Interaction between Learning Independence with Problem Based Learning Model (Problem Based Learning)

The result of SPSS version 20 analysis is calculated by 80,955 with $\mathrm{Sig}=0,000$. Because of the value of $\operatorname{Sig}<\alpha(0,05)$, it is interpreted there is interaction between students who have Higher Learning, Medium and Low Independence level in Problem Based Learning.

Furthermore to strengthen the conclusion above, the result of SPSS version 20 analysis presented ANOVA from Interaction Level of Independence Learning with Problem Based Learning Model as follows:

TABLE VIII. ANOVA INTERACTION INDEPENDENCE LEARNING WITH PBL PBL

\begin{tabular}{|l|l|l|l|l|l|}
\hline & \multicolumn{1}{|c|}{$\begin{array}{c}\text { Sum of } \\
\text { Squares }\end{array}$} & \multicolumn{1}{|c|}{ Df } & \multicolumn{1}{|c|}{$\begin{array}{c}\text { Mean } \\
\text { Square }\end{array}$} & \multicolumn{1}{|c|}{ F } & Sig. \\
\hline Between Groups & 4284.654 & 2 & 2142.327 & 80.955 & .000 \\
Within Groups & 1693.644 & 64 & 26.463 & & \\
Total & 5978.299 & 66 & & & \\
\hline
\end{tabular}

Based on the result of Anova $3 \times 2$ test above, it can be concluded that there is an overall Interaction between Learning Independence and Problem Based Learning Model that affect the high thinking ability of the students of SMPN Purwakarta.

The third hypothesis: There is a Difference Effect of Problem-Based Learning Model on Higher Thinking Ability Students SMPN Purwakarta with High Independence

In an effort to answer this hypothesis, through the results of SPSS version 20 analysis, the Group Statistics table shows the results of descriptive statistical analysis of the mean per group, standard deviation, and standard error. 
The results of the analysis show that: (a) the amount of valid data is 38 people from the high degree of independence (22 students with Problem Based Learning and 16 students with conventional learning); (b) the average grade of learningbased learning 76,27 and the average value of conventional learning class 62,19; and (c) standard deviations of 3.49 and 4.34 respectively.

Furthermore, the Independent Samples Test table shows a two-group difference test (Problem Based Learning and Conventional from high degree of independence). The test results show that the value of $\mathrm{t}$ arithmetic $=11.081$ and the value of sig $(2$ tailed $=0,000)<1 / 2 \alpha(0.05)$. Thus it can be interpreted that there are differences in the influence of problem-based learning model on the ability of high-level thinking of students SMPN Purwakarta on a high degree of independence. In other words Problem Based Learning (Problem Based Learning) affects the ability of high thinking for learners who have high independence. It can also be stated that problem-based learning is effective in improving the ability of high-level thinking for learners who have the characteristics of thinking as always set goals in learning, determine strategies to solve problems, and not quickly satisfied with the results obtained. Summary of SPSS version 20 analysis results are presented in table 9 below:

TABle IX. Pengaruh PBL terhadaP Kemampuan Berpikir TingGi PADA TingKat KEMANDIRIAN TingGI

\begin{tabular}{|c|c|c|c|c|c|c|c|}
\hline \multirow{3}{*}{$\begin{array}{c}\text { INDEPEN } \\
\text { DENCY }\end{array}$} & \multicolumn{4}{|c|}{ Learning Model } & \multirow{3}{*}{$\mathbf{T}$} & \multirow{3}{*}{$\begin{array}{c}\text { Sig } \\
(2- \\
\text { tailed } \\
)\end{array}$} & \multirow{3}{*}{$\begin{array}{c}\text { Besar } \\
\text { Perbed } \\
\text { aan }\end{array}$} \\
\hline & \multicolumn{2}{|c|}{$P B L$} & \multicolumn{2}{|c|}{$\begin{array}{c}\text { KONVEN- } \\
\text { SIONAL }\end{array}$} & & & \\
\hline & $\bar{x}$ & $S d$ & $\bar{x}$ & Sd & & & \\
\hline High & 76,27 & 3,49 & 62,19 & 4,34 & 11,081 & 0,000 & 14,08 \\
\hline
\end{tabular}

Fourth Hypothesis: Differences in Effect of Problem Based Learning Model on Higher Thinking Ability Student of SMPN Purwakarta with Medium Independence

In an effort to answer this hypothesis, through the results of SPSS version 20 analysis, the Group Statistics table shows the results of descriptive statistical analysis of the mean per group, standard deviation, and standard error.

The results of the analysis show that: (a) the amount of valid data is 39 people from the level of moderate independence (23 students with Problem Based Learning) and 16 students with Conventional Learning); (b) the average grade of Problem-Based Learning 66,91 and the average grade of Conventional Learning 49,38; and (c) standard deviations of 1.93 and 3.7 respectively.

Furthermore, the Independent Samples Test table shows the test of difference of the two groups (Problem Based Learning and Conventional from the level of independence is) show that the value of $t$ arithmetic $=21.019$ and the value of sig ( 2 tailed $=0,000)<1 / 2 \alpha(0.05)$. Thus it can be interpreted that there are differences in the influence of problem-based learning model on the ability of high-level thinking of students Purwakarta SMPN on the level of independence is. In other words Problem Based Learning (Problem Based Learning) affects the ability to think high. Summary of SPSS version 20 analysis results are presented in table 10 below:

TABLE X. INFLUENCE OF PBL ON THINKING ABILITY AT MEDIUM INDEPENDENCE LEVEL

\begin{tabular}{|c|c|c|c|c|c|c|c|}
\hline \multirow{3}{*}{$\begin{array}{c}\text { INDEPEN } \\
\text { DENCY }\end{array}$} & \multicolumn{3}{|c|}{ Learning Model } & \multirow{4}{*}{$\begin{array}{c}\text { KONVEN- } \\
\text { t }\end{array}$} & $\begin{array}{c}\text { Sig } \\
\text { (2- } \\
\text { tailed) }\end{array}$ & $\begin{array}{c}\text { Differe } \\
\text { nce }\end{array}$ \\
\cline { 2 - 5 } & $\bar{x}$ & Sd & $\bar{x}$ & Sd & & & \\
\hline Middle & 66,91 & 1,93 & 49,38 & 3,07 & 21,916 & 0,000 & 17,53 \\
\hline
\end{tabular}

Fifth Hypothesis: There is a Difference Effect of ProblemBased Learning Model on Higher Thinking Ability Students SMPN Purwakarta with Low Independence

In an effort to answer this hypothesis, through the results of SPSS version 20 analysis, the Group Statistics table shows the results of descriptive statistical analysis of the mean per group, standard deviation, and standard error.

The results of the analysis show that: (a) the amount of valid data is 38 people from low self-reliance level (22 students with Problem Based Learning) and 16 students with Conventional Learning); (b) the mean grade of Problem-Based Learning 56.55 and the average grade of the conventional learning class 34,69; and (c) standard deviations of 8.03 and 7, 36 respectively.

Furthermore, the Independent Samples Test Table shows the test of difference of the two groups (Problem Based Learning and Conventional from the low level of independence) indicates that the value of $t$ arithmetic $=8.571$ and the value of sig $(2$ tailed $=0,000)<1 / 2 \alpha(0,05)$. Thus it can be interpreted that there are differences in the effect of problem-based learning model on the ability of high-level thinking of students of SMPN Purwakarta at low level of independence. In other words Problem Based Learning (Problem Based Learning) affects the ability to think high. Summary of SPSS version 20 analysis results are presented in table 11 below:

TABLE XI. INFLUENCE OF PBL ON THINKING ABILITY

\begin{tabular}{|c|c|c|c|c|c|c|c|}
\hline \multirow{3}{*}{$\begin{array}{c}\text { INDEPEN } \\
\text { DENCY }\end{array}$} & \multicolumn{4}{|c|}{ Learning Model } & \multirow{3}{*}{$\mathbf{t}$} & \multirow{3}{*}{$\begin{array}{c}\text { Sig } \\
(2- \\
\text { tailed } \\
\quad)\end{array}$} & \multirow{3}{*}{$\begin{array}{c}\text { Difere } \\
\text { nce }\end{array}$} \\
\hline & \multicolumn{2}{|c|}{$P B L$} & \multicolumn{2}{|c|}{$\begin{array}{c}\text { KONVEN- } \\
\text { SIONAL }\end{array}$} & & & \\
\hline & $\bar{x}$ & $S d$ & $\bar{x}$ & $S d$ & & & \\
\hline Rendah & 56,55 & 8,03 & 34,69 & 7,36 & 8,571 & 0,000 & 21,86 \\
\hline
\end{tabular}

\section{E. Discussion}

1) Differences in the Level of Thinking between Students Using Problem-Based Shopping Models with Overall Conventional Model on PAI Learning Aspects of Morals

There is a difference of high thinking ability of learners who use problem-based learning model with conventional learning on learning PAI aspect Akhlak. These conclusions show that high-order thinking is determined by a problembased learning model. Since the beginning of learning the learners have been faced with problems that must be solved through the process of thinking by analyzing, looking for possible solutions to the problem and verification through the 
collection of information and data from various sources. This is in line with the theory of reflective thinking learning [7] and critical thinking [8].

\section{2) Interaction between Independence with Problem-Based} Learning Model on PAI Learning Aspects of Morals

There is an interaction between independence and the problem-based learning model that affects the thinking ability of high-level learners. This proves that the application of problem based learning needs to be supported by the independence of learners. But not always the higher the independence of learners, as well as to improve the ability of high-level thinking. Students with moderate and low independence, improved high-order thinking skills greater than learners with high self-reliance. This thinking theory is in line with the theory of independent dependent thinking style [9].

3) Influence of Problem-Based Learning Model on Higher Thinking Ability Students SMPN Purwakarta with High Independence

Problem-based learning model affects the ability of highlevel thinking for learners who have high independence. This explains the interaction of the problem-based learning model with independence. It also shows that for students with high independence can use problem-based learning models to achieve high-level thinking skills. This is in line with the theory of cognitive styles as described above [7].

4) Effect of Problem-Based Learning Model on Higher Thinking Ability Students SMPN Purwakarta with Independence Medium

Problem-based learning model affects the ability of highlevel thinking for learners who have moderate independence. For learners with moderate independence, problem-based learning models have been shown to improve higher-order thinking skills better than learners with high self-reliance. Basically independence is showing that learners are less able to fully determine their own thinking choices. The ability of highlevel thinking for learners with moderate independence is much in the embrace by considerations of his friends. This is in line with the theory of thinking style and the tendency to solve problems [10].

5) Effect of Problem-Based Learning Model on Higher Thinking Ability Students SMPN Purwakarta with Low Independence

Problem-based learning model affects the ability of highlevel thinking for learners who have low independence. Highlevel thinking skills that are influenced by problem-based learning for learners with low self-reliance are shown to be higher than learners with high self-reliance and are lower than learners with moderate independence. This is in line with the ability to make decisions in thinking by considering input from others. Thinking analysis and evaluation requires decisions to determine which parts are analyzed and evaluated [11].

\section{CONCLUSION}

Based on the results and discussion of the research can be concluded that problem-based learning and independence have a positive and significant effect on the ability of high-level thinking in students in SMPN Purwakarta. Problem-based learning and learning independence is an important aspect in the effort to improve high-order thinking in learning PAI aspects of morals.

\section{ACKNOWLEDGMENT}

Speech and appreciation submitted by the author to Tarbiya and Teacher Faculty of UIN Sunan Gunung Djati Bandung. This conference activity is supported by Quality Assurance Institution, UIN Sunan Gunung Djati Bandung. Quality Assurance Institution.

\section{REFERENCES}

[1] Vijayaratnam, P. (2012). Developing Higher Order Thinking Skills and Team Commitment via Group Problem Solving: A Bridge to the Real World. Procedia - Social and Behavioral Sciences, 66, 53-63. https://doi.org/10.1016/j.sbspro.2012.11.247

[2] Richland, L. E., \& Simms, N. (2015). Analogy, higher order thinking, and education. Wiley Interdisciplinary Reviews: Cognitive Science, 6(2), 177-192. https://doi.org/10.1002/wcs.1336

[3] Yee, M. H., Yunos, J. M., Othman, W., Hassan, R., Tee, T. K., \& Mohamad, M. M. (2015). Disparity of Learning Styles and Higher Order Thinking Skills among Technical Students. Procedia - Social and Behavioral Sciences, 204, 143-152. https://doi.org/10.1016/j.sbspro.2015.08.127

[4] Yen, T. S., \& Halili, S. H. (2015). Effective teaching of higher-order thinking (HOT) in education. The Online Journal of Distance Education and E-Learning, 3(2), 41-47.

[5] Thomas, A., \& Thorne, G. (2009). How to increase higher order thinking. Metarie, LA: Center for Development And. Retrieved from http://www.studentachievement.org/wpcontent/uploads/How_to_Increase_HOT.doc

[6] Heong, Y. M., Yunos, J. M., Othman, W., Hassan, R., Kiong, T. T., \& Mohamad, M. M. (2012). The Needs Analysis of Learning Higher Order Thinking Skills for Generating Ideas. Procedia - Social and Behavioral Sciences, 59, 197-203. https://doi.org/10.1016/j.sbspro.2012.09.265

[7] Mahasneh AM. The relationship between Reflective Thinking and Learning Styles among Sample of Jordanian University Students. Journal of Education and Practice. 2013;4(21):50-5.

[8] Emir S. Contributions of Teachers' Thinking Styles to Critical Thinking Dispositions (Istanbul-Fatih Sample). Educational Sciences: Theory and Practice. 2013;13(1):337-47.

[9] Ahiri, J., Dunifa, L., Tanduklangi, A., Ghani, A, R, A. 2013. The Effect of Learning 126 Strategies on Higher-Order Thinking Skills Students with Different Learning Styles. International Journal of Science and Research (IJSR). ISSN (Online): 2319-7064.

[10] P. Setyosari, D. Kuswandi, and W. D. Dwiyogo, "The Effect of Learning Strategy and Cognitive Style toward Mathematical Problem Solving Learning Outcomes," vol. 6, no. 3, pp. 137-143, 2016.

[11] Budsankom P, Sawangboon T, Damrongpanit S, Chuensirimongkol J. Factors affecting higher order thinking skills of students: A metaanalytic structural equation modeling study. Educational Research and Reviews. 2015 Oct 10;10(19):2639. 